\title{
É preciso saber viver, é preciso saber viver... (Titãs)
}

\author{
Guilherme Malafaia
}

Departamento de Ciências Biológicas, Instituto Federal Goiano (IF Goiano) - Urutaí (GO), Brasil. E-mail: guilhermeifgoiano@gmail.com

Houve um tempo em que a tarefa de publicar uma pesquisa científica era vista por seus protagonistas, tanto pesquisadores quanto a própria comunidade acadêmica, como algo pleno de sentido. Isso não está tão distante a ponto de só ser lembrado pelos mais velhos ou pelos filhos daqueles apóstolos científico-culturais. Ainda são muitos os que acreditam que assim é e continuará sendo. Esses são aqueles que acreditam que a ciência busca enunciar leis gerais consideradas suficientes para explicar o universo físico, valendo-se de um método, do discurso lógico e, fundamentalmente, admitindo que suas conclusões sejam provisórias.

Contudo, proliferam, e às vezes ruidosamente, os que asseguram que já não é mais assim. Atualmente tem-se instigado com frequência a reflexão: para que serve a ciência? Para assegurar um processo civilizatório, capaz de beneficiar toda a humanidade, ou para abarrotar de lucros os cofres de algumas empresas? Tais questões revestem-se de importância nos dias de hoje, principalmente porque temos constatado que a avaliação do desempenho acadêmico tem valorizado, sobretudo, a produção e publicação de estudos relacionados à área de atuação dos pesquisadores. Nesse sentido, a elaboração e publicação de artigos científicos passam a ser vistas, por alguns, como algo até mais importante do que a própria pesquisa que o sustenta. De quem é a culpa desse sistema? Quem está certo e quem está errado? Há certos e errados? O vilão seria o sistema de estratificação estabelecido pela Coordenação de Aperfeiçoamento de Pessoal de Nível Superior (CAPES) como critério para avaliação (e ranking) dos programas de pós-graduação e do Currículo Lattes de pesquisadores no Brasil? Resposta: talvez sim, talvez não.

Não é difícil percebermos que na atualidade há posições divergentes quando tocamos nesse assunto. De um lado constatamos aqueles que são favoráveis ao sistema, tomando como principal argumento o fato desse sistema estimular a produção e delimitar parâmetros objetivos de avaliação dessa produção. De outro, destacam-se aqueles que assumem o referido sistema como um grande equívoco da área acadêmica, alegando principalmente que o mesmo perverte o princípio da liberdade reflexiva e "força" os pesquisadores a divulgar resultados preliminares de pesquisa, quando não incompletos. Muitos desses acreditam que o atual sistema de avaliação acadêmica da CAPES não tem como diferenciar a produção criativa da produção em escala, e receia-se que, por isso, acabe por dar guarida à segunda.

Porém, há que se pensar que tal sistema pode ser um passo definitivo e que a supressão dos indicadores quantitativos do sistema ou mudança radical do Currículo Lattes seja impossível. Nesse caso, talvez o mais coerente fosse assumir, em meio ao debate acirrado, posições intermediárias, ou seja, aquelas que procuram avaliar e julgar os vícios e virtudes do sistema. Talvez seja preciso repensar os limites e intenções de uma argumentação contra a pressão pela publicação.

Daí pode-se pensar: para que publicamos? Para quem? Há sempre em ciência um público alvo a ser atingido? A ética na publicação parece ser um elemento importante que proporciona certo equilíbrio e sustentação para assumirmos posições intermediárias sobre o atual sistema. Um passo importante a ser dado seria refletirmos constantemente sobre a pesquisa que estamos desenvolvendo, a fim de evitar publicações de trabalhos que pouco contribuem para o avanço do conhecimento nas diferentes áreas. Artigos apenas elaborados para "alongar" o Currículo Lattes do pesquisador, nada contribuem para a ciência! Assim, não apenas é necessária a realização de uma avaliação rigorosa e acurada dos manuscritos que são submetidos aos periódicos, mas também é importante que os pesquisadores adotem uma postura séria e ética, no sentido de que, ao proporem um estudo, constatem anteriormente que realmente os objetivos propostos ainda não foram estudados, que os métodos estabelecidos para alcançarem os objetivos propostos não apresentam sérias limitações e que os prováveis resultados contribuirão, de fato, com o desenvolvimento da ciência ou com o aumento de conhecimento sobre um aspecto específico.

A métrica do tempo e a busca da eficiência que é imposta pelo um ritmo de vida acelerado vivenciado atualmente sugere que podemos fazer mais em menos tempo e que a produtividade tende a ser maior, gerando melhores resultados para quem consegue vencer os ponteiros do relógio. Mas é preciso ponderar e considerar que nem sempre o "rápido" deve ser tido como sinônimo de normal, de produtivo, moderno e eficiente. Do mesmo modo, o "lento" como sinônimo de anormal, de improdutivo, atrasado e ineficiente não deve ser a regra. Assim, o desafio atual parece nem ser a abolição desse sistema "produtivista" e "de pressão por publicações", uma vez que suas dimensões são complexas e grandes demais, mas sim o de disseminar no meio acadêmico-científico a ideia da ponderação, da prioridade e da ética na pesquisa. Nesse sentido, um passo importante a ser dado seria valorizar e estimular práticas de ensino ou ações que mostrem ou que promovam a discussão da importância do tempo para pensar, para planejar, para desenvolver o plano, escrever, pensar de novo e depois tentar publicar. De uma coisa estejamos certos: excesso de bons artigos, resultantes de uma investigação bem planejada, conduzida de forma ética, não parece, em princípio, ser um problema!? 